\title{
THE ANATOMY OF TAX EVASION ANDTAX MORALE: LESSONS FROM TAX THEORIES, TAX AUDITS AND SURVEYS IN ZIMBABWE
}

\author{
Joe Muzurura $^{1}$, Josphat Nyoni ${ }^{2}$ and Leo Mataruka ${ }^{3}$ \\ ${ }^{1}$ Midlands State University, Zimbabwe \\ ${ }^{2}$ Women's University in Africa \\ ${ }^{3}$ Catholic University of Zimbabwe
}

DOI: 10.46609/IJSSER.2021.v06i04.011 URL: https://doi.org/10.46609/IJSSER.2021.v06i04.011

\begin{abstract}
Tax evasion is a serious developmental issue in many developing countries. Efficient tax collection is critical for the building and maintenance of public infrastructure. The purpose of the paper was to examine factors that encourage tax evasion in Zimbabwe using evidence from tax audits and theory. The findings show that tax morale, tax administration inefficiencies, taxpayer attitude, existence of shadow economy, ineffective tax audits, high marginal tax rates, corruption and lenient penalties are some of the major factors that causes tax evasion in Zimbabwe. The study recommends the adoption of policies that encourage high tax morale such as making tax design systems less complex, using tax revenues efficiently in order to encourage positive attitude and trust in the government. Stringent penalties, long jail terms, forfeiture of tax evasion rentals should be made mandatory for those caught evading and also to deter would be tax evaders. Making tax audits effective and efficient in order to reduce the perception of unfairness, progressively reducing tax rates and gradually automating tax systems to minimise human interface are some of the policies that can be used to reduce incidences of tax evasion in developing countries. Data was collected using surveys of 100 individuals, firms as well as finding from tax audits. The contribution of this study is the use of binary choice models to analyse factors that contributes to the probability of tax evasion.
\end{abstract}

Keywords: Tax evasion. Tax audits. Tax morale, Logit model, Developing Countries, Zimbabwe

\section{Introduction and Background}

An effective tax revenue mobilisation strategy has remained an elusive goal even though being a critical success factor for economic performance of most developing countries like Zimbabwe. Minimising tax revenue losses from tax evasion enables a country to build and maintain quality public infrastructure such as energy and water utilities, communication networks, schools, hospitals and other social amenities. However, the efficient collection of optimum tax revenues 


\section{International Journal of Social Science and Economic Research}

ISSN: $2455-8834$

Volume:06, Issue:04 "April 2021"

is perhaps one of the major and contemporary challenges that face not only Zimbabwe but many developing and developed countries (Dharmapala, 2017; Kovermann and Velte, 2019). The scope and distribution of tax evasion and its likely effect on corruption and money laundering has alsobeen attracting sustained interest from developmental economists and policy makers (Alm et al., 2016; Jones et al., 2017; Alstadsæter et al., 2018; Nygard et al, 2019; Guo and Hun, 2020).

Tax evasion reduces national resources needed for developmental goals such as the financing of pro-poor programs, institutional capacity and enhancing economic growth and development. Tax evasion intensifies inequalities an inequities in the society and hence, accelerates poverty and socio-economic instabilities. Zimbabwe has under-developed public infrastructure, yet tax revenues can be used by the government to stimulate and catalyse economic growth and development. More significantly, the potential collectable tax revenue in Zimbabwe is much bigger than the taxation revenues that are being presently being collected (Muzurura, 2019). Since the financial crisis that began in 2007 and still ongoing, the gap between tax revenue and government spendingis continuously increasing, hence, threatening the attainment of social development goals and other economic gains achieved by similar developing countries after the turn of the new millennium.Tax evasion decelerates the pace of human capital development whilst at the same time diverting potential government revenues towards rent seeking behaviour, corruption and money laundering (Christensen, 2011; Alm et al., 2016; Chernykh and Mityakov, 2017).In Zimbabwe, like other developing countriestax evasion has become a more popular way of accumulating primitive wealth, illegal rent-seeking and money laundering (Gamze and Erdal, 2013;Alstadsæter et al., 2018).

Tax evasion exacerbates fragilities in the financial sector which in turn increases inefficiencies in the allocation of domestic savings to the desired productive investment (Guo and Hun, 2020; Kemme et al., 2017; Demir and Jarvocik, 2020). If tax evasion and low tax morale are large, the government is forced to optimally choose fiscal and monetary policies that promotes inflation financing (Muzurura, 2018). Tax evasion creates unfairness in the whole tax system, distorts the redistribution element of the tax system and results in unfair and inequitable distribution of the tax burden among economic agents (Nygard et al., 2019; Kessler and Norton, 2015).Taxpayers with similar incomes end up paying different amounts of tax hence, widening the socioeconomic inequalitiesbetween those that evade taxes and those that are compliant with tax laws. Fairness and efficient collection of taxes requires that equals should pay equal taxes. Tax evasion has a huge impact on the relative cost of labour supply, competition and trade competitiveness (Kessler and Norton, 2015; Golkap et al., 2017; Khalif and Achek, 2015; Gamse and Erdal, 2013). The decision to evade taxes is important for the design of a country's tax systems and 


\section{International Journal of Social Science and Economic Research}

ISSN: $2455-8834$

Volume:06, Issue:04 "April 2021"

public policy because it fundamentally alters the relevant demand and supply elasticities (Muzurura, 2018).

In countries with high inflation rates like Zimbabwe, optimising the country's revenue capacity is often saddled with significant challenges. For instance, the Zimbabwe Revenue Authority (ZIMRA), the country's tax collection agent, often carries out unplanned or random check-ups of financial statements prepared and submitted by taxpayers to them. If a taxpayer is caught shirking taxes the firm or individual taxpayer is either prosecuted or forced to pay a penalty that is relative to the amount of the taxes that has been evaded. However, random tax audits, inspections or examinations of a tax payer's affairs are carried out a long time after the year of assessment. This poses three major problems to the fiscal authority. The first problem is that the country's economy is characterised by high structural rigidities, hyper inflation and poor governance that accentuate administrative problems in designing an efficient tax systems.

Second, due to high audit costs caused by large numbers of people employed in the informal sector, tax audits or inspections are unsystematic. For example, audits commonly occur one or more years after taxpayers have submitted their tax payable reports. Due to hyperinflation, it is possible that the hyperinflation environment modifies the real returns of the risky investment that is implied in tax evading activities (see Tanzi, 1977; Olivera, 1967). We argue that under a hyperinflation equilibrium tax payers will rather risk not paying taxes as they fully know that future fines and penalties at the time of payment would have been eroded by inflation. This problem is aggravated by the impact of uncertainty about the auditor's assessment and the rate of penalty if caught dodging particularly if the taxpayer's preferences of tax evasion does not exhibit decreasing absolute risk aversion. The third problem is that the fraction of taxation revenue in total revenues raised by governments as a percent is very high, reaching upwards of $95 \%$ of the total budget. This makes it a huge challenge for the country to keep on increasing tax rates with creating excess burden on few taxpayers in order to fund not only growing budgetary deficits but to achieve economic stability. The questions why evade taxes, who evade taxes and by how much remains central in many empirical research that focus on both developed and developing countries (Kleven et al., 2011;Bernasconi and Corazzini, 2014; Hashmidzode et al., 2013).The perception of unfairness and inefficiency held by taxpayers affects their trust, faith or confidence in government and public institutions that uses tax revenues. If taxpayers have high trust in the government this may in turn impact their decision to comply or to evade taxes. There is likely a positive relationship between trust and higher tax morale. Within a given society, the more people evade paying taxes the higher the probability of tax evasion (Kemme et al., 2018).Many studies in both developed and developing countries have focused mainly on the individual tax evasion and tax avoidance dimensions (see Yee et al., 2017; Kovermann and Velte, 2019). Tax avoidance occurs when an individual alters his or her behaviour in such a 


\section{International Journal of Social Science and Economic Research}

ISSN: $2455-8834$

Volume:06, Issue:04 "April 2021"

manner in order to reduce his legal tax liability. Thus, tax avoidance can be seen as the reorganisation of economic activities by the taxpayer in order to take advantage of tax provisions and laws so as to reduce tax liability. Many a time courts in both developing and developing countries have ruled that one can arrange one's financial businesses in order to ensure that tax payables are minimised. In contrast, tax evasion is failing to pay taxes willingly when they are legally due. Tax evasion can also be perceived as the purposeful failure by economic agents to declare taxable economic activities to taxation authorities when required. In Zimbabwe like many other progressive countries, tax evasion is illegal and a subject of criminal prosecution, and the reason why it is the subject of this study.

This study is significant for the following reasons. (1)Many researchers have investigated the relationship among tax rates, tax evasion and tax morale by borrowing from the neoclassical models of tax evasion (see Amew and Dzaka, 2015; Kemme et al., 2017; Yee et al., 2017;Kovermann and Velte, 2019).Most of these studies have produced diverse, inconclusive explanations and debatable antidotes for reducing tax evasion even in developed economies (see Kemme et al., 2017; Sikka, 2016, Halla, 2012).Furthermore, these prior studies have investigated several aspects of tax evasion that are related to income under-reporting in the context of developed economies (Halla, 2012; DeBacker et al., 2015; Nygard et al., 2019; Kemme et al., 2018). The subject of tax evasion has not received intensive interrogation in developing economies given the urgent need to eradicate corruption and money laundering activities.

(2) There are growing sentiments in many developing countries that using neoclassical frameworks of tax evasion without significant modification may notbeaptly capture the effects of tax evasion in the context of developing countries like Zimbabwe (Muzurura, 2019; Annan et al., 2010; Ameyaw and Dzaka, 2015).Unlike some developing countries, Zimbabwe has idiosyncratic characteristics as reflected in increased financial and capital markets volatilities, huge shadow economies, endemic corruption, high inflation, and elevated socio-political instability. Such business operating environments enable economic agents to pay bribes and wilfully evade taxes without fear of prosecution.

(2).An implicit assumption in most researches that focus on tax evasion in developed countries is that firms and consumers in all their consciences report their taxable activities honestly to tax authorities (Bernasconi and Corazzini, 2014; Dharmapala, 2017; Kahlif and Achek, 2015).However, this assumption when confronted with actual reality that faces Zimbabwe's economy may be manifestly defective. Social norms, endemic corruption, weak governance, mistrust of the government and abuse of tax revenue by politicians and senior bureaucrats suggest that individuals are likely to have low tax morale and high propensity to engage in tax evasion.(3) Taxes impose an economic cost on the taxpayer. In real practice, this cost is not simply an amount of money that the tax payer hands over to the tax authority. There are some 


\section{International Journal of Social Science and Economic Research}

ISSN: $2455-8834$

Volume:06, Issue:04 "April 2021"

important social, political and economic issues that surround the payment of taxes. For instance, taxes distort economic decisions made by individuals, households and corporations. Inefficient tax systems create an excess burden that leads to loss of welfare for producers and consumers. The deadweight loss caused by tax evasion is above and beyond the taxes revenue that the government collects. In the labour market, Pigovian taxes amplify the excess burden through reduction in wages and also distorts work incentives. The higher the perceived loss of welfare or deadweight loss the greater the chances of higher rates of tax evasion. Even more important, the greater the perception that the government cannot implement an optimal tax policy or the realisation that the tax policy is inconsistent with the government incentives over time, the greater the propensity to evade the tax.

(4) The subject of tax evasion is also a typical case of the principal agent problem. It is possible that tax authorities observe outcomes that are correlated with the tax payer's actions but not the actions of tax evasion themselves, (also known as moral hazard or hidden-action). For instance, when tax payers perceive that the design of tax system as discriminating, regressive and that their tax evasion activities are unobservable by tax authorities, they are unlikely to voluntarily pay taxes. The presence of huge shadow economy in Zimbabwe where most core income generating activities occur increases information asymmetries between economic agents and tax authorities, thus producing more opportunities of tax evasion. Tax evasion is likely to be high in Zimbabwe because financial and operating activities in the shadow economy are not only opaque, but are also not properly recorded, measured and accounted for.It is therefore likely to be easier to bribe tax authorities in the shadow economy than in the formal sector where rules of good corporate governance are not observed and followed.

(5) Even though most developing countries face huge challenges regarding high tax evasion,Zimbabwe is a typical case study for tax evasion studies in developing countries. The country consistently ranks in the top ten of the most corrupt countries in the world outside war zones (Transparent International, 2019). It is also one of the few countries with the lowest social trust in government and has the second highest inflation in the world. At least $90 \%$ of the labour force is employed in the shadow economy, and it is estimated that only 15 percent of individuals and 10 percent of firms are voluntarily paying taxes (GOZ, 2019). This suggest a higher level of tax evasion compared to other developing countries. Against this background, the main purpose of this paper is to use econometric regression tore-examine the Allingham and Sandmo theory of tax evasion by incorporating findings from random tax audits done by Zimbabwe Revenue Authority and the Zimbabwe's Auditor General. Using a structured questionnaire we also survey the views of 100 respondents. In this way, our approach departs from studies that rely only on secondary data derived from random audits of firms only. Our contribution to literature is in the use of logit regression model to examine why individuals and firms evade paying taxes in the 


\section{International Journal of Social Science and Economic Research}

ISSN: $2455-8834$

Volume:06, Issue:04 "April 2021"

context of developing countries. The paper is structured as follows; section one looks at the introduction and the background of the paper. The second part reviews empirical literature followed by the methodology in section three. The final sections covers findings, conclusions and recommendations.

\section{Theoretical Review}

The study of tax evasion is old, dating back to Becker (1968) and Allingham and Sandmo (1972). In the traditional theory of tax compliance also known as the neoclassical theory of tax evasion that was advanced by Allingham and Sandmo (1972), economic agents (individuals) do not pay taxes if the marginal benefit that comes from tax evasion is greater than the marginal cost associated with cheating and later being discovered by tax authorities. The neoclassical theory of tax evasion suggests tax authorities should increase the marginal costs related to tax evasion (Allingham and Sandmo, 1972; Sandmo, 1981; Sandmo, 2005). This can be done by increasing the number of effective random tax audits and associated penalties. According to Sandmo (2005), the expected marginal cost of tax evasion is a product of the penalty rate and the likelihood of being apprehended by tax authorities. If the possibility of being discovered as a cheater through random audits is low and the penalty is also low chances are that taxpayers may be unwilling to pay taxes. Alternatively if one uses the expected utility models to analyse tax evasion, the preferences of cheating or complying can be represented by a utility function that has an expected utility property If the taxpayer at all times select his/her most preferred substitute available to him, then that taxpayer will select or bet with tax evasion above compliance. This happens only when the expected utility of tax evasion exceeds the utility arising from tax compliance causing such a taxpayer to be called expected utility maximiser.

In the Allingham and Sandmo (1979) model, the tax rate effect on tax evasion was addressed using the income effect and substitution effect.In this model the substitution effect of tax rates is downward sloping and negative, showing that if there is an increase in rates of taxation, economic agents find it profitable to evade taxes. However, the model finds that the income effect fluctuating, and that it depend on the absolute risk aversion of the taxpayer. When the absolute risk aversion of the taxpayer either decreases, or remains constant or increases, the income effect will be positive, zero, or negative, respectively. According to this model, the income effect of tax rates is likely to reduce the evasion of tax. Arisein marginal tax rates under diminishing absolute risk aversion reduces the taxpayer's income, and in turn lessens the taxpayer predisposition concerning risk aversion. Consequently, with higher marginal tax rates, the probability of tax evasion also increases.

Nevertheless, Yitzhaki (1974) and Percavel (1979) argue that if one considers the effects of penalties on undeclared income the argument for the substitution effect of tax rates becomes 


\section{International Journal of Social Science and Economic Research}

ISSN: $2455-8834$

Volume:06, Issue:04 "April 2021"

binding. Under decreasing absolute risk aversion a rise in tax rate causes a reduction in tax evasion. Many researchers have applied the penalty to the evaded tax and not to undeclared income by extending Allinghamand Sandmo (1981) model (Slemrod, 2007; Porteba, 1987; Chen, 2003). Cowell (1981)also examined the impact of work and leisure choices on tax rates and incorporated income as an exogenous variable. The challenge with these modifications is that it is still not clear whether an increase in the marginal tax rate promotes evasion of taxes or not. For instance, Alllingham-Sandmo model tax evasion assumes some form of non-reporting of a fraction of the individual's gross income. We argue that the holding of constant the penalty rate can result in a lot of ambiguities. This is because in most developing countries penalty rates are frequently a proportionate of the evaded tax.

\section{Empirical Literature Review}

Factors that contribute to tax evasion are multifaceted and dynamic and have been classified into three broad classifications in empirical literature. In the first category are factors that are related to tax morale, ethical rules and perceptions (Alms and Torgler, 2011; Saeed and Shah, 2011; Alm and McClellan, 2012; Luttmer and Sighal, 2014; Lee, 2016; Kemme et al., 2020). The second category of factors is concerned about whether the tax system is fair or not, and how it is enforced (Khalif and Achek, 2015; Thomas, 2015; Lumir et al., 2017). The fairness of the tax system is likely to affect the taxpayers' willingness to comply with taxation rules of a country. The third category regards the taxpayers' perception of how transparently taxation revenue are being used by the government (DeBacker et al., 2015; Alleyne and Harris, 2017 Alms and McChlellan, 2017; Dharmapala, 2017).

Most times-series analyses on individual countries find a negative effect of the shadow economy and tax evasion and lower tax morale (Alm and McClellan, 2012). In contrast, some crosssectional surveys report a very weak or an insignificant link between the size of the underground economy and tax evasion (Guo and Hun, 2020; Thomas, 2015; Luttmer and Sighal, 2014; Torgler and Schneider, 2009).Dharmapala (2017) reports that tax policies that increase the certainty of detection after tax audits and higher penalties forces people to reduce tax evasion. Slemrod and Weber (2012) show that an increase in uncertainty regarding the assessment of taxable income by the tax auditor lowers tax evasion assuming that the taxpayer's preference exhibit decreasing absolute risk aversion.

Lago-Penas (2010) demonstrated that age, financial stress, religion, and concurrence with how government manages increase tax morale. They also show that the level of education and selfemployment reduce tax morale. Cummings et al (2009) in a survey of Botswana and South Africa showed that high tax morale increased tax compliance. Kemme et al (2018) show that tax evasion in firms is caused by low trust in government and weak institutions of governance such 


\section{International Journal of Social Science and Economic Research}

ISSN: $2455-8834$

Volume:06, Issue:04 "April 2021"

as the judicial systems. They also find higher of perceptions of high corruption and higher compliance costs causing firms to evade taxes.Factors responsible for tax evasion include trade openness (Demir and Jarvocik, 2020; Guo and Hun, 2020), tax audits and tax ethics (Dharmapala, 2017; Kahlif and Achek, 2015; Alms and Torgler, 2012), shadow economy and tax havens (Schneider et al., 2015; Alm et al 2016; Sikka, 2015), role of stigma, social norms, tax knowledge, tax fairness, and enforcement levels (Santos-Pinto et al., 2015; Litina and Palivos, 2016; Akhter et al., 2019; Allen and Harris, 2017; Abraham eta 1., 2016), the quality of publicexpenditure, taxpayers' moral attitude and culture (Alm and Torgler, 2011; Arms and McClellan, 2012; Young et al., 2013; Luttmer and Sighal, 2014; Allen and Harris, 2017; Golkap et al., 2015),nature of country governance and corruption (Akhatar et al., 2019; Kovermann and Vettel, 2019), the perceived unfairness of the tax system (Luttmer and Singhal, 2014; Nygard et al., 2019; Thomas, 2015), per capita income, the average tax rate, age, inflation and firm-size (Dharmapala, 2017; Khalif and Achek, 2015; Chernykh and Mityakov, 2017), gender (Torgler and Velev, 2010), low tax morale, less economic freedom, ineffective competition laws and weak moral norms (Gamze and Erdal., 2013; Slemrod and Weber, 2012; Kemme et al., 2020; Abraham et al., 2017; Lee, 2016 Saeed and Shah, 2011), tax policies (Piollatto and Rablen ,2016), uncertainties of tax audits (Alm and McClellan, 2012), income earned (Alstadsæter et al., 2018; Kemme et al., 2018), round tripping ( Hanlon et al., 2015; Kemme et al., 2017), moral costs of tax evasion, social stigma and taxpayer's attitude towards honesty ( DelleAnno, 2009).

\section{Methodology}

Tax evasion has largely been examined using the general equilibrium models based on the neoclassical theory to tax evasion (example see Kesselman, 1989; Girtner and Wenig, 1985). The standard expected utility was used by Watson (1985). Muzurura (2019)substituted the risk of detection and penalty by utilising an ad hoc disutility of tax evasion. Most researchers have tended to use laboratory studies, game theory, differences between consumption and income, studying individual returns and using estimates of tax capacity to get closer to the goal of studying tax evasion (see Torgler, 2012; Kemme et al., 2017, 2018; Hanlon et al., 2015). Other adopted portfolio-based models for examining the evasion of tax (Landskroner et al., 1990). These models often neglect the differences in willingness of individuals and firms to pursue tax evasion efforts, disregard the extent to which the substitutability in consumption between services and goods of the evasion and non-evasion sectors, and the composition of government expenditure. The neo classical theory of tax evasion has also some shortcomings. It is premised on feeble grounds that believe that most economic agents are likely to pay taxes because of (1) fear of stiff penalties and (2) if the probability of being caught cheating is high. We argue that most taxpayers are rational and maximise utility when they assess the cost and benefits of evading taxes and therefore, are likely to consider some non-pecuniary factors in their decision 


\section{International Journal of Social Science and Economic Research}

ISSN: $2455-8834$

Volume:06, Issue:04 "April 2021"

to comply or to evade. Thus, we modify the Allingham and Sandmo (1972) tax evasion model to include these factors. We start by arguing that in many developing countries the decision to pay tax is done under uncertainty of being detected. The failure to report taxable income to tax authorities by individuals and firms does not instantly elicit a punitive response in the form of penalties. Due to uncertainty of detection after random tax audits the taxpayer may choose two options; truthfully declare his actual income or under-declare the income, hence two decisions. We denote the tax payer's decision as a binary choice with two dependent variables; 1 -evade tax and 0-not evade taxes. For this reason, we can use binary choice models such as Linear Probability Models, Probit, Logit and Tobit models instead of the commonly used ordinary least square regression models. If the tax payer elects to choose tax evasion as his/her dominant strategy the final outcome or return (payoff) will depend on the decision by the tax authorities to investigate him or not. If tax authority decides to carry out an investigation of the taxpayer's financial returns the outcome is likely to be a worse off for the tax payer.

We thus consider that the axioms of choice under uncertainty, that is the axioms of completeness, transitivity, substitution, monotonicity, and continuity as holding in our final model. Furthermore, ifwe accept the behaviour of the taxpayer under uncertainty follows the VonNeumann-Morgenstern Utility axioms, we can represent a taxpayer's preference with a continuous, real valued function. In this case, the cardinal utility function of the taxpayer has income as its only argument (see Slemrod and Weber, 2012; Torgler, 2012). This becomes an indirect utility function which has unchanging income. We can also assume that the marginalutility will be always positive and exactingly declining. This makes the tax payer risk averse and the final outcome is income Q. Income Q is taken as an exogenous variable that is given and is known by the taxpayer only and not by the tax authority due to information asymmetries and may deserve hidden-type solutions.

Assume that tax is charged on declared income $Y$ at a rate $\beta$ which is constant. Note that the taxpayer makes a decision to choose the level of $Y$ to declare to tax authorities. Let us denote $p$ to represent some odds that the tax authority will investigate the taxpayer, and in the process of investigation will get to know the exact taxable amount. Let's assume that the tax authority decides to carry out tax audits. If after investigation the tax payer is caught cheating the taxpayer will have to pay tax on the under declared taxable amount that is equivalent to $\$(\mathrm{Q}-\mathrm{Y})$ and a penalty of $\$ \phi$, which is higher than $\beta$. For reasons of maintaining simplicity we leave out the option of jail terms that are existent in different tax jurisdictions and also uncertainty on the exact amount of the penalty rate $\phi$.

With these assumptions, a taxpayer will select $Y$ so as to maximise his expected utility as in equation (1) 
$E(U)=(1-p) U(Q-\beta Y)+p U(Q-\beta Y-\phi(Q-Y)$

Adopting the following notations

$X=Q-\beta Y$,

$W=Q-\beta Y-\phi(Q-Y)$

We can derive the first order condition for an interior maximum for equation (1)and show it as in equation (4)

$-\beta(1-p) U^{\prime}(X)-(\beta-\phi) p U^{\prime}(W)=0$

The second order condition given by

$S=\beta^{2}(1-p) U^{\prime \prime}(X)+(\beta-\phi)^{2} p U^{\prime \prime}(W)$

The equation holds due to concavity of the utility function assumption.

An interior solution exist at $Y=0$ and $Q=Y$ and if the expected marginal utility decreases with $W$.

Equation (5) is reduced to equation (6) as follows, assuming that the anticipated marginal utility is diminishing with $W$;

$\frac{d E(U)}{d x} \mid x-0=-\beta(1-p) U^{\prime}(Y)-(\beta-\theta) p U^{\prime}(Y(1-\theta))>0$

(6) The

first order conditions can be rewritten as follows

$p \phi>\beta\left\lfloor p+(1-p) \frac{U^{\prime}(Y)}{U^{\prime}(Y(1-\beta))}\right\rfloor$

$p \phi<\beta$

Equation 8 shows that the taxpayer is likely not to pay the required tax whenthe anticipated tax that is due on the under declared income is a smaller amount than the normal rate. As also shown Equation(7) is positive and greater than one. This two conditions guarantee an interior solution. As was done by Allingham and Sandmo (1972) we can modify equation (1) by adding variable a $t$ in the utility function.

$E(U)=(1-p) U\left(W, t_{0}\right)+p U\left(X, t_{1}\right)$

We further assume that;

$U\left(X, t_{0}>\left(X, t_{1}\right)\right.$.

The first order condition is now shown as follows;

$-\beta(1-p) D_{1}\left(W, t_{0}\right)-(\beta-\phi) p D_{1}\left(W, t_{1}\right)=0$

Where $D_{l}$ is the first derivative of $D$ with respect to the income and must hold for all $W<X$. The second order condition becomes;

$\left.p \phi<\beta \mid p+(1-p) \frac{D_{1}\left(Y(1-\beta) \cdot t_{0}\right.}{D_{1}\left(Y(1-\beta), t_{1}\right.}\right]$

If $p \phi$ is less than 1 and $\left[p+(1-p) \frac{D_{1}\left(Y(1-\beta) . t_{0}\right.}{D_{1}\left(Y(1-\beta), t_{1}\right.}\right]$ is less than 0 , tax morale is low and hence an opportunity for profitable tax evasion. 


\subsection{Data and Logistical Regression Construction}

Under uncertainty the decision to evade tax by an individual is unlikely to be linear. On the contrary, a tax payer can either choose tax evasion (1) or compliance (0). These two distinct choices depend on the odds of being caught on the wrong side by the tax authorities. Under such a scenario, it is possible to use probabilistic distribution functions to analyse the likely cause of tax evasion in developing countries. For practical reasons we chose the Logistical regression function of the form;

$P_{i}=E\left(Q=Y_{i}\right)=\beta_{1}+\beta_{2} Y_{i}$

Where $P_{i}$ is the probability of tax evasion and $Y_{i}$ are a set of independent variables.

We can further present equation (13) by adopting a cumulative logistic regression equation of the form;

$P_{i}=\frac{e^{y_{i \emptyset}}}{1+e^{y_{i \emptyset}}}=\frac{1}{1+e^{-\varnothing}}=\exists\left(y_{i}^{\varnothing}\right)$

Where $y_{i}{ }^{\varnothing}$ is a linear function that if take it the place ofA: $\Omega \backsim$ (zero) and $\mathrm{A}$ is take as a probability function lies between 0 and 1values (Muzurura, 2018). After some mathematical manipulation we can get.

$L=\oiint_{i=1}^{N} \Lambda\left\{\left(y_{i} \beta\right)^{y_{i}}\left(1-\Lambda\left(y_{i} \beta\right)\right\}^{1-y_{i}}\right.$

Using logarithms to linearize equation (15) we get

$\ln L=\sum_{i=1}^{N}\left\{y_{i} \ln \left[\Lambda\left(y_{i} \beta\right)\right]+\left(1-y_{i}\right) \ln \left[1-\Lambda\left(y_{i} \beta\right)\right]\right.$

Replacing (16) into (14);

$\ln K=\sum_{i=1}^{N}\left\{y_{i} \ln \left[\frac{1}{1+e^{-\beta y_{i}}}\right]+\left\{\left(1-y_{i}\right) \ln \left[1-\frac{1}{1+e^{-\beta y_{i}}}\right]\right\}\right.$

We can expand the equation by adopting a more familiar probability model specification as follows;

$$
\begin{aligned}
P(T E=1 / Y) & =\alpha_{0} T M+\alpha_{1} T A+\alpha_{2} G E+\alpha_{3} S E+a_{4} M T R+\alpha_{5} T A U+\alpha_{6} I N F+\alpha_{7} C O R \\
& +\alpha_{8} A G E+\alpha_{9} E D+\alpha_{10} I N C+\alpha_{11} P E N+\mu_{t}
\end{aligned}
$$

Where,

$P(T E=1 / Y)$, is the dependent variable representing the probability of choosing tax evasion (1) given a choice of tax compliance. Independent variables are Tax morale(TM).Tax payer's attitude (TA), Gender (GE), Shadow Economy (SE), marginal tax rate (TR), tax audits (TAU), Inflation (INF), corruption (CORR), Age (AGE), Education (ED), and Income (IC) and fines 
(FI). Kemme et al (2019) show a positive relationship between high tax morale and lower tax evasion. Torgler (2012) and Inglehart et al (2014) reports that an increase in corruption levels reduces tax morale and increase tax evasion. Dharmapala (2017) establishes a positive relation between marginal tax rates and high tax evasion. High inflation and lower income were found to increase tax evasion by Alms and McClellan (2012). Education, tax morale, age, fines and tax audits have been reported to be related to evasion (Alms and Torgler, 2012; Guo and Hun, 2020; Kemme et al., 2017). The shadow economy positively affects high tax evasion (Scheneider et al., 2015). Data was collectedusing surveys and tax audits of 100 taxpayers in Harare. $\alpha_{0}, \alpha_{1}, \alpha_{2}, \alpha_{3}, \alpha_{4}$, and $\alpha_{11}$ are expected to be positive, $\alpha_{5}, \alpha_{6}, \alpha_{10}$ to be negative whilst $\alpha_{7}, \alpha_{8}, \alpha_{9}$ to be statistically significant. All independent factors are dummy variables which equals 1 or otherwise zero. For example, if a respondent says corruption influences tax evasion the response is coded 1 and if not 0 .

\section{Findings}

Table 1 below reports the summary of descriptive statistics. Tax morale is $25 \%$ but can be seen as $40 \%$ of the respondents. The average number of respondents who indicated tax attitude are close to $1 \%$. Other variables which have high response rates are; shadow economy (16\%), Trust (18\%), inflation (45\%) and corruption (65\%). In general our sample has a high score for corruption and shadow economy.

\section{Table 1: Descriptive Statistics}

$\begin{array}{llllll}\text { Variable } & \text { Observation } & \text { Standard deviation } & \text { mean } & \min & \text { max } \\ \text { Tax morale } & 100 & 24.80 & 60.50 & 14 & 70 \\ \text { Tax Attitude } & 100 & 0.70 & 10.50 & 25 & 35 \\ \text { Gender } & 100 & 3.50 & 0.52 & 0 & 7 \\ \text { Shadow economy } & 100 & 10.79 & 6.20 & 35 & 55 \\ \text { Marginal tax rate } & 100 & 17.76 & 15.25 & 20 & 50 \\ \text { Tax Audits } & 100 & 0.30 & 18.08 & 15 & 25 \\ \text { Inflation } & 100 & 1.15 & 7.60 & 25 & 30 \\ \text { Corruption } & 100 & 55.55 & 35.5 & 18 & 65 \\ \text { Age } & 100 & 0.40 & 7.50 & 2.5 & 15 \\ \text { Education } & 100 & 3.37 & 0.12 & 0 & 1 \\ \text { Income } & 100 & 2.45 & 0.70 & 1 & 3 \\ \text { Penalties } & 100 & 30.31 & 0.80 & 15 & 25\end{array}$




\section{Source: own computation}

\section{Multicollinearity Tests}

Table 2 below shows the Pearson's Correlation matrix for our dependent variables. A correction of above $80 \%$ between two dependent variables indicates strong collinearity between these variables. Our result shows the highest coefficient of correlation is between the tax payer's AGE and Marginal Tax Rate (MTR) which is $35 \%$.We can conclude that there is no correlation among independent variables.

Table 2: Multicollinearity Tests

$\begin{array}{lllllllll}\text { TM } & \text { TA } & \text { GE } & \text { SE } & \text { MTR } & \text { TAU INF } & \text { COR AGE EDU INC PEN }\end{array}$

TM $\quad 1.00$

TA $\quad-0.18 \quad 1.00$

GE $\quad-0.10 \quad 0.01 \quad 1.00$

SE $\quad 0.25 \quad-0.11 \quad-0.07 \quad 1.00 \quad 1.00$

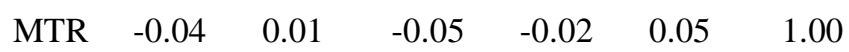

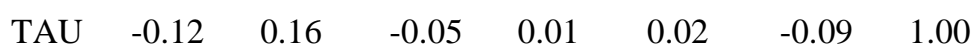

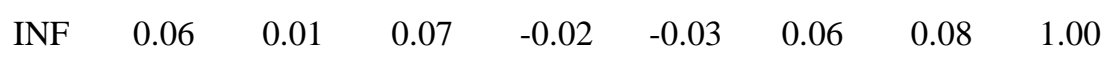

$\begin{array}{llllllllll}\text { COR } & -0.06 & -0.02 & -0.08 & -0.01 & 0.15 & -0.09 & -0.02 & -0.06 & 1.00\end{array}$

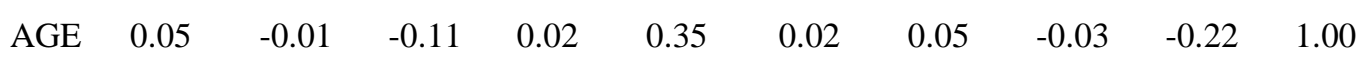

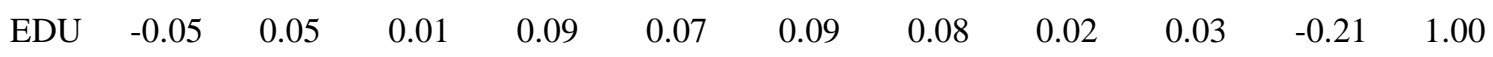

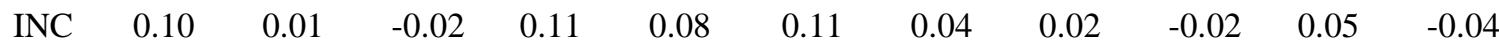

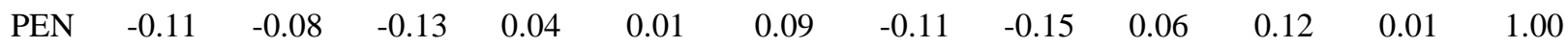

Source: Own computation

\section{Model Fitness Test}

As shown in table 3, the McFadden and Zaivona and Crag-Uhler (Nagellkerke) R-squared are 0.12 and 0.15 . They lie between 0 and 1indicating that our model is a good fit since it accounts for $100 \%$ of the variances. In addition, the probability> Chi measure is 0.00 showing that the model is statistically significant at $1 \%$ level. The findings of this robustness test strengthen the parsimony of our model and that this model can be used to examine factors that contribute to tax evasion in developing countries. 
International Journal of Social Science and Economic Research

ISSN: 2455-8834

Volume:06, Issue:04 "April 2021"

\section{Table 3: Model Fitness Test}

No of observations

No of covariate patterns

Pearson Chi2 (95)

Prob $>\mathrm{Chi}^{2}$

.fit stat

Measures of Fit for logit of tax evasion

Log-Lik Intercept only: $\quad-78.86$

$\mathrm{D}(91)$ :

McFadden's $\mathrm{R}^{2}$

ML (Cox-Snell) $\mathrm{R}^{2}$

McKelvey \& Zaivona's $\mathrm{R}^{2} 0.25$

Variance of $\mathrm{y}^{*}$

Count $\mathrm{R}^{2}$

AIC

BIC

BIC used by Stata
85.65

0.12

0.11

3.21

0.71

0.89

$-185.95$

125
100

100

98.95

0.72

\section{Logit Regression Output}

Table 4 below is the initial regression output and indicate that tax morale,Tax attitude, Tax Audits, Shadow Economy, Income, Marginal Tax Rates, Corruption, Inflation and Penalties cause individuals and firms to evade tax at different levels of significance. Socio-demographic factors such as age, genderand education have no impact on the probability of tax evasion. The coefficients of Tax morale, tax attitude, shadow economy, marginal tax rate, tax audits and penalties are positive and statistically significant at $1 \%$ and $5 \%$ level given that all other variables are held constant. The coefficients of corruption and inflation are negative and statistically significant on condition that all other variables are held constant in the model.

\section{Table 4: Logistical Regression model Output}

\footnotetext{
- Observations

Logit RegressionChi2 (100)

$\mathrm{P}>\operatorname{chi} 2$ (100)

Log likelihood is 200.15

Factor

Tax Morale (TM)

Tax Attitude (TA)

Gender (GE)

Shadow Economy (SE)

Marginal Tax Rate (MTR)

Tax Audits (TAU)
}

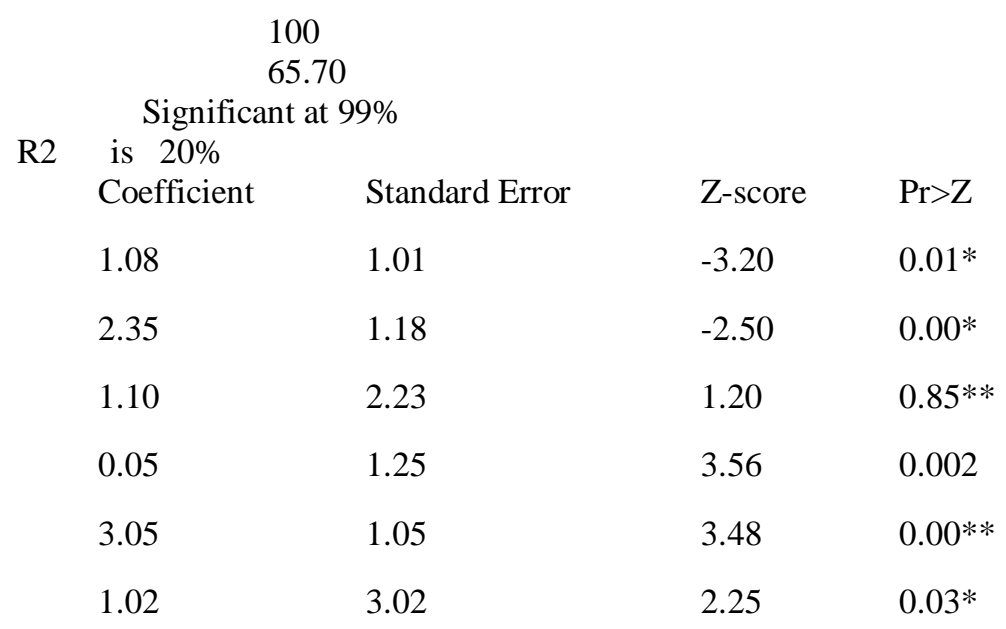


International Journal of Social Science and Economic Research

ISSN: 2455-8834

Volume:06, Issue:04 "April 2021"

$\begin{array}{lllll}\text { Inflation (INF) } & -1.10 & 0.44 & -3.98 & 0.03 \\ \text { Corruption (COR) } & -0.22 & 0.01 & -2.85 & 0.00^{* *} \\ \text { Age } & 0.20 & -0.07 & -1.08 & 0.25^{*} \\ \text { Education (EDU) } & -0.07 & 0.33 & 4.45 & 0.15^{*} \\ \text { Income (INC) } & 0.09 & 0.398 & 0.25 & 0.90 \\ \text { Penalties (PEN) } & -0.50 & 0.314 & 3.06 & 0.03 * \\ \text { Constant } & 2.33 & 1.18 & 4.05 & 0.00^{* *}\end{array}$

*95\% level, **99\% confidence

\section{Marginal Effects}

When using logistical regression equations, it is important that we analyse marginal effects. The marginal effect on a variable indicates the size of the effects of variations in predictor factors on the regressand variables. The marginal effect indicate what is the likely effect on tax evasion if there is a unit increase on an independent variable.

Table 5: Marginal Effects

$\begin{array}{llllll}\text { Factor } & \mathbf{\Delta} / \mathbf{\Delta} \mathbf{x}^{*} & \begin{array}{l}\text { Standard } \\ \text { Error }\end{array} & \mathbf{Z} & \mathbf{P}>|\mathbf{Z}| & \text { Mean } \\ \text { Tax Morale } & -0.45 & 0.01 & -4.25 & 0.00 & 9.48 \\ \text { TaxpayerAttitude } & -0.02 & 0.02 & -2.20 & 0.01 & 1.45 \\ \text { Gender } & 0.15 & 0.04 & 3.05 & 0.09 & 0.21 \\ \text { Shadow Economy } & 0.01 & 0.01 & 2.85 & 0.00 & 6.19 \\ \text { Marginal Tax Rate } & 0.12 & 0.09 & -2.09 & 0.04 & 0.10 \\ \text { Tax Audits } & -0.30 & 0.03 & -2.60 & 0.02 & 0.00 \\ \text { Inflation } & -0.02 & 0.01 & -0.56 & 0.90 & 18.29 \\ \text { Corruption } & 1.03 & 0.04 & -2.28 & 0.00 & 5.79 \\ \text { Age } & 0.01 & 0.05 & 3.05 & 0.02 & 3.16 \\ \text { Education } & 0.08 & 0.05 & 4.05 & 0.70 & 0.68 \\ \text { income } & 0.11 & 0.03 & 0.60 & 0.78 & 0.55 \\ \text { Penalties } & -0.70 & 0.02 & 3.05 & 0.00 & 3.78\end{array}$

[*] $\Delta \mathrm{y} / \Delta \mathrm{x}$ shows the discrete change of dummy variable from 0 to 1

\section{Source: own computation}

A percentage change in tax morale increases the likelihood of tax evasion by $45 \%$. This finding is consistent with a number of studies in other (see for example Abraham et al., 2016; Akhtar et al., 2019; Allen and Harris, 2017). A high tax morale among tax payers could also be a signal of trust in how the government is collecting and using tax revenues. If taxpayers see improvements in public infrastructure such as communication networks, health and social amenities they are likely to willingly pay taxes. Thus, high tax morale infers also trust in the government and shape 


\section{International Journal of Social Science and Economic Research}

ISSN: $2455-8834$

Volume:06, Issue:04 "April 2021"

individuals and firms attitude in complying with tax laws. This finding has a bearing on taxpayer's attitude where a unit increase in the tax payer's attitude reduces incidences of tax evasion by $2 \%$.If more individuals believe that other taxpayers are honesty, ethical and also believe in the integrity of the tax system design and administration, the more they adopt a positive attitude towards paying taxes voluntarily. On the contrary, if economic agents accept that others are evading taxes they are likely to adopt the same attitude leading to a low tax morale within an economy. A similar observation was confirmed by Lee (2016). These findings may also confirm the importance of cultural values, social moral norms as was reported in empirical literature (seeLuttmer and Sighal, 2014; Golkap et al., 2017).

The existence of a huge shadow economy was found to be positive such that increasing the size of the economy by $1 \%$ increases the probability of tax evasion by $110 \%$. The findings imply that most tax payers prefer to do their business in the informal sector where there activities are subject to less scrutiny and are hidden from tax authorities.Huge monitoring disincentives in the shadow economy, information asymmetries, hidden-type actions by taxpayers, incomplete accounting and financial records, and the cost of carrying out tax audits on millions of unregistered taxpayers makes operations in the shadow economy more rewarding. The findings also indicate that they may be a joint tax evasion where both consumers and sellers are likely to benefit from tax evasion. For instance, the tax payer reduces his or her tax burden by underdeclaring the taxable income whilst the consumer my gain from lower prices caused by the buyer's tax evading activities. The findings further suggest that a collusive tax evasion game with several equilibria social norms and is likely to promote more tax evasions. This findings has important implications formost developing countries where the shadow economies constitute the largest component in the economy. This finding is supported by empirical literature (Alms and McClellan, 2012;Santos-Pinto et al., 2015;Muzurura, 2018; Nygaard et al., 2019; Demir and Jarvocik, 2020).

A $1 \%$ increase in tax rates increases the probability of tax evasion by $12 \%$. Zimbabwe is one of the few countries with high taxation rates in the world and yet the quality of public infrastructure in one of the worst. This finding therefore suggest that increasing marginal tax rates without improving the provision of the lives of citizens might lead to more tax evasion in an economy. Furthermore, the result indicates that an increase in the marginal tax rate also raises the firm's cost of production cost and this may exacerbate financial constraints facing the taxpayer. The more the financial constraints facing the taxpayer, the more the likelihood of evading taxes, since tax evasion helps the taxpayer to solve the financial quagmires created by financial constraints. A number of studies that focus on developed countries confirm the finding (see Chernykh and Mityakov, 2017; Lumir et al., 2017; Dharmapala, 2017, Kovermann and Velte, 2019). 


\section{International Journal of Social Science and Economic Research}

ISSN: $2455-8834$

Volume:06, Issue:04 "April 2021"

Tax audits were found to be negative suggesting that reducing tax audits increases the probability of tax evasion by $30 \%$.This finding suggest that if tax payers are certain that they are not going to be audited, and also if they are certain that after the tax audit will not detect under declared income, then their level of compliance will be low. In addition, if there is higher levels of uncertainty regarding the effectiveness and efficiency of tax audits, tax payers tend to be risk takers. Warren and Snow (2005) also demonstrated a similar finding.A $1 \%$ increase in corruption within the economy raises the likelihood of tax evasion by $103 \%$. In any economy with high systemic corruption and rent seeking behaviour economic agents are likely to bribe tax authorities during tax audits and thus are able to under report their actual incomes. There is also a strong possibility that corruption and tax evasion have an endogenous relationship. For instance, our findings suggest that a country with high corruption enables more tax evasion as corrupt tax officials seek to increase their income by seeking bribes. On the other hand, tax evasion may cause more corruption within the society by offering more opportunities for more corruption rentals. The endogenous relationship between corruption and tax evasion is still a fertile area of future research, more so, if one considers the possibility of multiple self-fulling equilibria with various levels of corruption. Our finding on corruption is confirmed by numerous studies (see Muzurura, 2019; Guo and Jun, 2020;Litina and Palivos; 2016).Finally, if there is a 1\% increase in penalties for under-reporting taxable incomes, the probability of tax evasion decreases by $70 \%$. The effects of penalties and fines in reducing tax evasion has a lot of empirical support (DeBacker et al., 2015; Kemme et al., 2017)

\section{Conclusions and Recommendations}

The study investigated the factors that contribute to tax evasion in developing countries by drawing lessons from Zimbabwe. Tax morale, tax attitude, the shadow economy, marginal tax rates, tax audits, corruption and penalties are some of the factors which increases the likelihood of tax evasion in developing countries.Our contribution to literature is the use of a logistical regression model to examine factors that cause tax evasion in Zimbabwe. Besides providing recommendations to policy makers in developing countries, our study contributes to growing literature on tax evasion in developing countries given that that this area is still under-studied in most developing countries. The recommendations arising from the findings are that; Zimbabwe should institute policy measures that encourage high tax morale such as making tax design systems less complex, imposing high moral costs on those who evade tax, using tax revenue efficiently in order to encourage positive attitude and trust in the country's governance system. Severe penalties that includes long jail terms, forfeiture of tax evasion rentals should be enforced for those caught evading taxes and also to deter would be tax evaders. Making tax audits more effective, efficient and truly independent from political machinations reduces the perception of unfairness and corruption. The government should also progressively reduce tax 
International Journal of Social Science and Economic Research

ISSN: 2455-8834

Volume:06, Issue:04 "April 2021"

rates, must simplify tax payment procedures, gradually automate the tax design system to minimise human interface and corruption. Similarly, coming up with policies that increases the certainty of detection of tax evasion such as continuous training of tax auditors by international experts, reliance on modern information and communication technologies is likely to reduce incidences of tax evasion in Zimbabwe.

\section{References}

Abraham, M., Lorek, K. and Richter, F., (2016). Collusive Tax Evasion and Social Norms. International Tax and Public Finance, 24, 179-197.

Akhtar, S., Akhtar, K. J. and Wong, S. W., (2019). Multinational Tax Evasion: A Financial and Governance Perspective. Journal of Corporate Finance, Vol 57, 35-62.

Alleyne, P. and Harris, T., (2017). Antecedents of Taxpayers' intentions to engage in tax evasion: Evidence from Barbados. Journal of Financial Reporting and Accounting, 15(1): 13-45.

Allingham, M. G., \& Sandmo, A., (1972).Income tax evasion: A theoretical analysis.Journal of Public Economics, 1(3-4), 323-338.

Alm, J.and Torgler, B., (2011). Do ethics matter? Tax compliance and morality. Journal of Business Ethics, 101 (4): 635-651

Alm, J., \& McClellan, C., (2012). Tax moraleand tax compliance from the firm's perspective.

Kyklos, 65(1), 1-17.

Alm, J., Marinez-Vazquez, J. and McCllellan, C., (2016). Corruption and firm Tax Evasion, Journal of Economic Behaviour and Organisation, Vol. 124, 146-163.

Alm, J and Liu, Y., (2019). Financial Constraints and Firm Tax Evasion. International Journal of Tax and Public Finance, 26 (171): 102.

Alstadsæter, A., Johannesen, N. and Zucman G., (2018).Who owns the wealth in tax havens? Macro evidence and implications for global inequality. Journal of Public Economics, 162, 89100

Ameyaw B. and Dzaka D., (2015). The effect of personal income tax evasionon socio-economic development in Ghana: A case study of theinformal sector. British Journal of Economics, management and Taxation 10(4):1-14

Annan B, Bekoe W, Nketia-Amponsah E., (2010) Determinants of TaxEvasion in Ghana. International Journal of Economic Science Application Research 6:97-121 


\section{International Journal of Social Science and Economic Research}

ISSN: $2455-8834$

Volume:06, Issue:04 "April 2021"

Bernasconi, M., Corazzini, L., \& Seri, R., (2014). Reference dependent preferences, hedonic adaptation and tax evasion: Does the tax burden matter? Journal of Economic Psychology, 40, 103-118.

Chernykh, L and Mityakov, S., (2017). Tax Evasion and the role of Banks. Journal of Financial Economics, 26(3): 516-512.

Christensen, J., (2011). The looting continues: Tax havens and corruption. Critical Perspectives on International Business, 7 (2): 177-196

DeBacker, J., Heim, B. T. and Tran A., (2015). Importing corruption culture from overseas: Evidence from corporate tax evasion in the United StatesJournal of Financial Economics, 117 (1): 122-138.

Demir, B. and Javorcik, B., (2020). Trade Policy changes, tax evasion and Benford's Law. Journal of Development Economics, 144, 125-145.

Dharmapala, D., (2017). The economics of tax avoidance and evasion. The international library of critical writings in economics 334, Edward Elgar Publishing

Gamze, O.Y and Erdal, G., (2013). Determinants of Tax Evasion Behaviour: Empirical Evidence from Survey Data International Business and Management, 6(2), 15-23, 2013

Golkalp, O.N., Lee, S and Peng, M.W., (2017). Competition, Tax Evasion and Social Values. Journal of World Business, 52(2): 258-269.

Guo, J and Hun, F., (2020). Tax Evasion and Financial Development under Asymmetric information in Credit Markets. Journal of Development Economics Vol 145, 15-45.

Halla, M., (2012). Tax morale and compliance behaviour: First evidence on a causal link

The BE Journal of Economic Analysis \& Policy, 12 (1) 10-35.

Hashimzade, N., Myles, G. D., \& Tran-Nam, B., (2013). Applications of behavioural economics to tax evasion. Journal of Economic Surveys, 27(5), 941-977.

Jones, C., Temouri,Y. and Cobham A., (2017), Tax haven networks and the role of the Big 4 accountancy firms. Journal of World Business, 53 (2): 177-193

Kemme, D. M., Parikh, B. and Steignere, T., (2017).Tax havens, tax evasion and tax information exchange agreements in the OECD. European Financial Management, 23 (3): 519-543

Kemme, D. M., Parikh, B. and Steignere, T., (2020). Tax Morale and International Tax Evasion. Journal of World Business, 55(3): 102-155. 


\section{International Journal of Social Science and Economic Research}

ISSN: $2455-8834$

Volume:06, Issue:04 "April 2021"

Kessler, J. B. and Norton, M. I., (2015). Tax aversion in Labour Supply. Journal of Economic Development and Organisation, Vol 121, 15-28.

Khlif, H. and Achek, I., (2015).The determinants of tax evasion: A literature review. Managerial Law, 57 (5): 486-497.

Kleven, H. J., Knudsen, M.B., Kreiner, C.T., Pedersen, S. and E. Saez, E., (2011).Unwilling or unable to cheat? Evidence from a tax audit experiment in Denmark. Econometrica, 79 (3): 651692

Kovermann, J and Velte, P., (2019). The impact of corporate governance on corporate tax avoidance-A literature review. International Journal of Accounting, Audit and Taxation (36): 118

Lee, K., (2016). Morality, tax evasion and equity. Mathematical Social Sciences, 82, 97-104

Litina, H. and Palivos, T., (2016). Corruption, Tax Evasion and Social Norms. Journal of Economic Behaviour and Organisation vol. 124,164-177.

Lumir, A., Besnik, K., Pugh, G.and Hashi, I., (2017). Firm-level determinants of Tax Evasion in Transitional Economies. Economic Systems, 41(3): 354-365.

Luttmer, E. F. P. and Singhal, M., (2014). Tax morale.The Journal of Economic Perspectives, 28, 149-168

Muhammed M.M, Muhanimed A (2012). Reasons of tax avoidance andtax evasion: Reflection from Pakistan. Journal of Economic Behavioural Studies 4:217-222.

Muzurura. J., (2018).Firm-Level Investment Decisions under Uncertainty And Irreversibility In Zimbabwe's Private Firms. International Journal of Business, Economics and Management, 5(6):201-218)

Muzurura, J., (2019). The Dynamics of Firm-Level Investment Behaviour in Zimbabwe under Uncertainty, Corruption and High Taxation regime. Global Journal of Social Sciences 5(1): 2845 .

Nygard, O. E., Slemrod, J. and Thoresen, T. O., (2019). Distributional Implications of Joint Tax Evasion. The Economic Journal, 129(620): 1894-1923.

Piolatto, A. and Rablen, M. D., (2016).Prospect Theory of Tax Evasion: A Reconsideration of the Yitzhaki Puzzle. Theory and Decision, 82, 543-565.

Santos-Pinto, L., Bruhin, A., Mata, J., \& Åstebro, T. (2015). Detecting heterogeneous risk attitudes with mixed gambles. Theory and Decision, 79(4), 573-600. 
International Journal of Social Science and Economic Research

ISSN: 2455-8834

Volume:06, Issue:04 "April 2021"

Schneider, F., Raczkowski, K. and Mroz, B (2015). Shadow economy and tax evasion in the EU. Journal of Money Laundering Control, 18 (1): 34-51

Sikka, P., (2015). No accounting for tax avoidance. The Political Quarterly, 86 (3): 427-433

Saeed, A. and Shah, A., (2011). Enhancing tax morale with marketing tactics: A review of literature.African Journal of Business Management, 5 (35): 13559-13565

Slemrod, J. and Weber, C., (2012).Evidence of the invisible: toward a credibility revolution in the empirical analysis of tax evasion and the informal economy. International Tax and Public Finance, 19 (1): 25-53

Thomas K.D., (2015). The psychic cost of tax evasion. Business Collection and LawReview. 56, 617-670.

Torgler, B, (2012). Tax morale, Eastern Europeand European enlargement. Communist and PostCommunist Studies, 45, 11-25.

Torgler, B., Schneider, F., \& Schaltegger, C.,(2009). Local autonomy, tax morale, and theshadow economy. Public Choice, 144(1-2),293-321.

Vogel, J., (1974). Taxation and public opinion inSweden: An interpretation of recent survey data.National Tax Journal, 27, 499-513.

Yee, C., Moorthy, K. and Soon, W.C., (2017). Tax Payers Perception on Tax Evasion Behaviour: An Empirical Study in Malaysia. International Journal of Law and Management, 59(3): 8-15.

Young A, Danny C, Daniel H., (2013). A Study of the impact of Culture onTax Compliance in China. International Tax Journal 39, 33-46.

Yitzhaki, S. (1974). A note on income tax evasion: A theoretical analysis. Journal of Public Economics, 3(2), 201-202. 